\title{
Valuasi One Period Coupon Bond dengan Aset Mengikuti Model Geometric Brownian Motion with Jump Diffusion
}

\author{
Meiliawati Aniska ${ }^{1}$, Di Asih I Maruddani ${ }^{2}$, dan Suparti ${ }^{3}$ \\ 1,2,3 Departemen Statistika, Universitas Diponegoro \\ maruddani@live.undip.ac.id
}

\begin{abstract}
One period coupon bond gives coupon once a bond life together with the principal debt. If the firm's asset value on maturity date is insufficient to meet the debtholder's claim, then the firm is stated as default. The well-known model for predicting default probability is KMV-Merton model. Under this model, it is assumed that the return on the firm's assets is distributed normally and their behaviour can be described with the Geometric Brownian Motion (GBM) formula. In practice, most of the financial data tend to have heavy-tailed distribution. It indicates that the data contain some extreme values. GBM with Jump is a popular model to capture the extreme values. In this paper, we evaluate a corporate bond which has some extreme condition in their asset value and predicts the default probability in the maturity date. Empirical studies were carried out on bond that is issued by CIMB Niaga Bank that has a payment due in November 2020. The result shows that modelling the asset value is more appropriate by using GBM with Jump rather than GBM modelling. Estimation to CIMB Niaga Bank equity in November 2020 is IDR $246,533,573,844,229.00$. The liability of this company is IDR $4,205,751,155,771.00$. The prediction of CIMB Niaga Bank default probability is $1.065812 \times 10^{-8}$ at the bond maturity. It indicates that the company is considered capable of fulfilling the obligations at the maturity date.
\end{abstract}

Keywords: jump diffusion, extreme value, probability default, equity, liability

\section{Pendahuluan}

Sektor finansial merupakan salah satu sektor yang paling banyak diminati dalam berinvestasi. Investasi dalam sektor finansial dapat berupa investasi terhadap surat-surat berharga. Salah satu bentuk instrumen investasi finansial tersebut adalah investasi pada obligasi. Obligasi merupakan surat hutang jangka menengah-panjang yang dapat dipindah tangankan, yang berisi janji dari pihak yang menerbitkan untuk membayar imbalan berupa bunga pada periode tertentu dan melunasi pokok hutang pada waktu yang telah ditentukan kepada pihak pembeli obligasi tersebut. One period coupon bond adalah jenis obligasi yang memberikan keuntungan (kupon) sebanyak satu kali yang dibayarkan bersamaan dengan nilai pokok obligasi pada saat jatuh tempo.

Risiko yang berpotensi menyebabkan kerugian dapat juga terjadi disamping keuntungan yang diperoleh. Salah satu risiko yang terdapat ketika berinvestasi pada obligasi adalah risiko kredit. Risiko kredit terjadi apabila pada saat jatuh tempo perusahaan penerbit obligasi tidak mampu membayar kewajibannya, yaitu membayar kupon dan pokok obligasi sehingga dinyatakan bangkrut [1]. 
Ada tiga ukuran risiko kredit perusahaan dalam rangka valuasi perusahaan, yaitu nilai modal atau ekuitas (equity), nilai hutang atau liabilitas (liability), dan probabilitas kebangkrutan (probability of default) [2]. Untuk memperhitungkan risiko kebangkutan tersebut dapat digunakan valuasi terhadap aset obligasi. Metode yang sering digunakan untuk melakukan valuasi terhadap obligasi adalah dengan metode Merton yang asetnya mengikuti model Geometric Brownian Motion (GBM). GBM digunakan untuk memprediksi pergerakan harga aset dalam periode jangka pendek [3]. Trimono dkk. [4] meneliti tentang model GBM untuk mengukur risiko data saham.

Beberapa penelitian terdahulu menunjukkan bahwa pergerakan data-data keuangan terindikasi mengandung data ekstrem yang dikenali dengan keberadaan lompatan (jump) ataupun excess kurtosis. Pemodelan dengan metode yang dapat digunakan untuk melihat efek jump tersebut [5]. Oleh karena itu model GBM kemudian dikembangkan menjadi Geometric Brownian Motion dengan Jump Diffusion (GBM Jump). Pemodelan data saham pada PT Aneka Tambang Tbk dengan GBM Jump memberikan akurasi prediksi harga saham yang sangat baik [6]. Pengukuran risiko dengan memperhatikan keberadaan data ekstrem pada data saham PT Astra Argo Lestari Tbk dengan GBM Jump juga menghasilkan ukuran risiko yang akurat [7].

Valuasi obligasi dengan data aset perusahaan sebagai underlying asset ditemukan juga bahwa pengaruh skewness dan kurtosis merupakan faktor penting dalam valuasi obligasi [8]. Model Gram-Charlier dengan momen ketiga dan keempat menghasilkan ukuran risiko yang lebih baik [9]. Secara umum efek nilai ekstrem yang ditambahkan pada pemodelan memberikan valuasi obligasi yang lebih baik [10].

PT Bank CIMB Niaga Tbk atau yang lebih dikenal dengan Bank CIMB Niaga merupakan salah satu bank terbesar yang berdiri di Indonesia. Penelitian ini bertujuan melakukan valuasi pada obligasi yang dikeluarkan oleh Bank CIMB Niaga dan menentukan peluang kebangkrutan perusahaan tersebut pada saat obligasi jatuh tempo. Underlying assets bulanan PT Bank CIMB Niaga Tbk pada periode Januari 2012 hingga Desember 2016 terindikasi mengandung data ekstrem, sehingga GBM Jump merupakan metode yang tepat untuk diterapkan dalam kasus ini.

\section{Kerangka Teoritis}

2.1. Geometric Brownian Motion (GBM). Prediksi data berdasarkan GBM didasarkan pada asumsi bahwa data berdistribusi normal [11] dengan model sebagai berikut 


$$
\widehat{V}_{t_{i}}=\widehat{V}_{t_{i-1}} \exp \left(\left(\left(\hat{\mu}-\frac{1}{2} \hat{\sigma}^{2}\right)\left(t_{i}-t_{i-1}\right)\right)+\left(\hat{\sigma} Z_{i-1} \sqrt{\left(t_{i}-t_{i-1}\right)}\right)\right)
$$

dengan

$$
\begin{array}{ll}
\hat{V}\left(t_{i}\right) \quad \text { : nilai estimasi total aset pada waktu ke- } t_{i} \\
\hat{V}\left(t_{i-1}\right): \text { nilai estimasi total aset pada waktu ke- } t_{i-1} \\
\hat{\mu} \quad: \text { nilai ekspektasi return aset } \\
\hat{\sigma} \quad: \text { volatilitas aset } \\
Z_{i-1} \quad: \text { data bangkitan berdistribusi normal baku }
\end{array}
$$

2.2. Jump Diffusion. Jump Diffusion merupakan fungsi eksponensial proses Lèvy dengan model [12]:

$$
S_{t}=S_{0} e^{L t}
$$

dengan total aset $\left\{S_{-} t ; 0 \leq t \leq T\right\}$ dimodelkan sebagai fungsi eksponensial dari proses Lèvy $\left\{L_{t} ; 0 \leq t \leq T\right\}$. Proses Lèvy merupakan gerak Brown dengan drift (proses difusi kontinu) ditambah dengan proses Poisson (proses jump diskontinu) sehingga [13]:

$$
L_{t}=\left(\alpha-\frac{\sigma^{2}}{2}-\lambda k\right) t+\sigma W_{t}+\sum_{i=1}^{Q_{i}} Y_{i}
$$

dengan

$$
\begin{array}{ll}
\left\{\mathrm{W}_{\mathrm{t}} ; 0 \leq \mathrm{t} \leq \mathrm{T}\right\} & : \text { gerak Brown Standar } \\
L_{t}=\left(\alpha-\frac{\sigma^{2}}{2}-\lambda k\right) t+\sigma B_{t} & : \text { gerak Brown dengan drift } \\
\sum_{i=1}^{Q_{i}} Y_{i} & : \text { proses Poisson dengan jump. } \\
\mu \text { dan } \sigma & : \text { rata-rata dan standar deviasi pada model GBM } \\
\lambda & : \text { intensitas. }
\end{array}
$$

2.3. Geometric Brownian Motion with Jump Diffusion (GBM Jump). GBM Jump diberikan oleh persaman [10]: 


$$
V(t)=\left(\mu-\frac{1}{2} \sigma^{2}-\lambda k\right) t+\sigma W(t)+\sum_{i=1}^{Q_{i}} Y_{i}
$$

Persamaan diferensial stokastik pada GBM Jump mengikuti persamaan

$$
\frac{d V(t)}{d t}=(\mu-\lambda k) d t+\sigma d W(t)+\left(y_{t}-1\right) d Q(t)
$$

dengan $\mu$ adalah rata-rata $\ln$ return aset, $\sigma$ adalah volatilitas atau standar deviasi dari $\ln$ return aset, $W(t)$ merupakan gerak Brown, $Q(t)$ adalah proses Poisson dengan intensitas $\lambda$ [14].

Penyelesaian GBM Jump dapat diperoleh dengan Teorema Itô [15]. Apabila terdapat fungsi $G=G(V, t), V=V_{T}-V_{t}$, maka berdasarkan Teorema Itô fungsi tersebut dapat dinyatakan sebagai berikut

$$
\begin{aligned}
d G= & \left(\frac{\partial G}{\partial V} \mu V+\frac{\partial G}{\partial t}+\frac{1}{2} \frac{\partial^{2} G}{\partial V^{2}} \sigma^{2} V^{2}\right) d t+\frac{\partial G}{\partial V} \sigma V d W(t) \\
& +G(V(t+\Delta V t)-G(V(t)))
\end{aligned}
$$

Misal fungsi $G=\ln V$, dengan $\frac{\partial G}{\partial V}=\frac{1}{V}, \frac{\partial^{2} G}{\partial V^{2}}=-\frac{1}{V^{2}} \operatorname{dan} \frac{\partial G}{\partial t}=0$, maka dari persamaan (2) diperoleh

$$
\begin{aligned}
d G= & \left(\frac{1}{V}(\mu-\lambda k) V+0+\frac{1}{2}\left(-\frac{1}{V^{2}}\right) \sigma^{2} V^{2}\right) d t+\frac{1}{V} \sigma V d W(t) \\
& +G(V((t+\Delta V t)-G(V(t)) \\
= & \left(\mu-\frac{1}{2} \sigma^{2}-\lambda k\right) d t+\sigma d W(t)+\left(\ln y_{i}\right)
\end{aligned}
$$

maka diperoleh model akhir total aset perusahaan GBM dengan Jump sebagai berikut

$$
\widehat{V}_{t_{i}}=\widehat{V}_{t_{i-1}} \exp \left(\left(\left(\hat{\mu}-\frac{1}{2} \hat{\sigma}^{2}-\hat{\lambda}\right)\left(t_{i}-t_{i-1}\right)\right)+\left(\hat{\sigma} Z_{i-1} \sqrt{\left(t_{i}-t_{i-1}\right)}\right)+N_{i}\right)
$$

dengan :

$\hat{V}\left(t_{i}\right) \quad$ : nilai estimasi total aset pada waktu ke $\mathrm{t}_{\mathrm{i}}$ 


$$
\begin{array}{ll}
\hat{V}\left(t_{i-1}\right) & : \text { nilai estimasi total aset pada waktu ke } \mathrm{t}_{(\mathrm{i}-1)} \\
\hat{\mu} & : \text { nilai ekspektasi return aset } \\
\hat{\sigma} & : \text { volatilitas aset } \\
Z_{i-1} & : \text { data bangkitan berdistribusi normal baku } \\
\hat{\lambda} & : \text { intensitas jump } \\
N_{i} & : \text { data bangkitan berdistribusi normal ke-i. }
\end{array}
$$

2.4. Peak Over Threshold (POT). Peak Over Threshold (POT) merupakan sebuah metode yang digunakan untuk mengidentifikasi data yang mengandung nilai ekstrem atau jump. Banyaknya jump yaitu $10 \%$ dari data. Nilai ambang yang disebut dengan threshold ditentukan dari banyaknya jump +1 . Data yang mengandung jump dipilih berdasarkan pada data yang berada di atas nilai ambang batas atas threshold, dan yang berada di bawah nilai ambang batas bawah threshold [5].

2.5. Ekuitas. Ekuitas adalah sisa atas total aktiva perusahaan yang telah dikurangi dengan semua kewajiban dalam neraca. Ekuitas akan berkurang karena adanya penarikan aset kembali oleh pemilik, pembagian keuntungan, atau karena kerugian. Jika dimisalkan suatu perusahaan dengan nilai total aset $V t$, dengan kewajiban membayar hutang (face value) sebesar $K$, pergerakan nilai total aset mengikuti $G B M$, suku bunga bebas risiko dinotasikan dengan $r$, besar kupon obligasi adalah $c$ dan waktu jatuh tempo obligasi adalah $T$, maka pada saat jatuh tempo terdapat dua kemungkinan keadaan, yaitu :

1. Jika nilai aset lebih dari atau sama dengan pokok hutang ditambah kupon $\left(K+c=K_{1}\right)$ yaitu $V_{t} \geq K_{1}$, maka penerbit obligasi akan membayar kepada investor sebesar $K_{1}$, sedangkan penerbit obligasi memiliki modal atau ekuitas sebesar $V_{t}-K_{1}$.

2. Jika nilai aset kurang dari pokok hutang ditambah kupon yaitu $V_{t}<K_{1}$, maka penerbit obligasi memiliki modal atau ekuitas sebesar 0 artinya penerbit obligasi bangkrut.

Gambaran keadaan untuk satu kali periode pembayaran kupon ditunjukkan dalam Gambar 1, sedangkan nilai keuntungan (payoff) pada saat jatuh tempo dapat diberikan pada Tabel 1. 


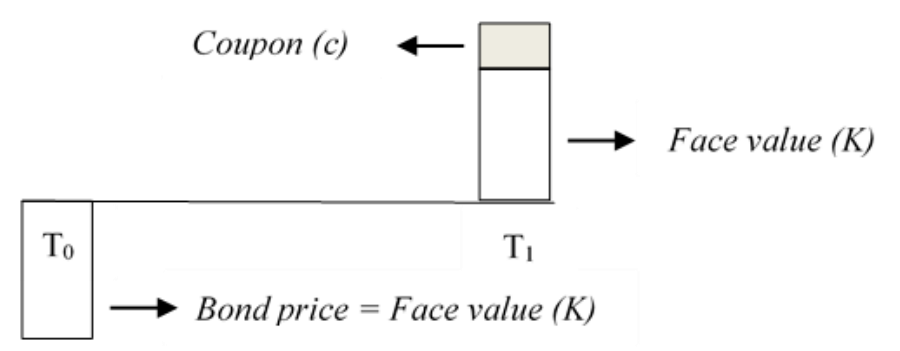

Gambar 1. Arus Kas Satu Kali Periode Pembayaran Kupon

Tabel 1. Payoff atau Ekuitas saat Jatuh Tempo

\begin{tabular}{llll}
\hline Keadaan & Aset & Obligasi & Ekuitas \\
\hline Tidak Bangkrut & $V_{t} \geq K_{1}$ & $K_{1}$ & $V_{t}-K_{1}$ \\
Bangkrut & $V_{t}<K_{1}$ & $V_{t}$ & 0 \\
\hline
\end{tabular}

Jika nilai ekuitas dengan nilai utang (face value) $K$ mengikuti model Merton dengan GBM Jump dan diasumsikan bahwa jump berdistribusi lognormal maka nilai ekuitas untuk model GBM Jump adalah

$$
\xi\left(V_{T}, \tau\right)=\sum_{i=0}^{\infty}\left[\frac{e^{-\bar{\lambda} \tau}(\bar{\lambda} \tau)^{i}}{i !}\right] \xi_{B S}\left(V, \tau=T-t, K_{1}, \sigma_{i}^{2}, r_{i}\right)
$$

$i$ adalah skenario dimana ke- $i$ terjadi, dengan

$$
\begin{aligned}
& \bar{\lambda}=\lambda(1+k) \\
& \sigma_{i}^{2}=\sigma^{2}+\frac{i}{\tau} \delta^{2} \\
& r_{i}=r-\lambda k+i \frac{\ln (1+k)}{\tau}
\end{aligned}
$$

dengan $\delta^{2}$ merupakan variansi dari model GBM Jump dan $k$ adalah rata-rata dari ukuran aset jump. $\frac{e^{-\bar{\lambda} \tau}(\bar{\lambda} \tau)^{i}}{i !}$ merupakan probabilitas Poisson dari total aset jump waktu $i$ selama interval $\tau$. Jika $\lambda=0$ maka $\xi\left(V_{T}, \tau\right)=\xi_{B S}$, sehingga setiap bentuk penjumlahan adalah sama dengan 0 kecuali untuk $j=0$ ketika $x_{0}=x$ dan $\sigma_{0}=\sigma . \xi_{B S}$ merupakan nilai ekuitas Black-Scholes dengan GBM yang mempunyai persamaan 


$$
\xi_{B S}=V_{0} N\left(d_{1}\right)-K_{1} e^{-r T} N\left(d_{2}\right)
$$

dengan

$$
\begin{array}{r}
d_{1}=\frac{\ln \left(\frac{V_{0}}{K_{1}}\right)+\left(r+\frac{\sigma^{2}}{2}\right) T}{\sigma \sqrt{T}} \\
d_{2}=\frac{\ln \left(\frac{V_{0}}{K_{1}}\right)+\left(r-\frac{\sigma^{2}}{2}\right) T}{\sigma \sqrt{T}}
\end{array}
$$

2.6. Liabilitas. Liabilitas adalah utang yang harus dilunasi atau pelayanan yang harus dilakukan di masa yang akan datang pada pihak lain. Liabilitas merupakan kebalikan dari nilai ekuitas yang dimiliki. Berdasarkan struktur modal sederhana aset suatu perusahaan, liabilitas dan ekuitas dapat diperoleh nilai liabilitas (utang) perusahaan sebagai berikut

$$
F\left(V_{T}, \tau\right)=V_{T}-\xi\left(V_{T}, \tau\right)
$$

2.7. Probabilitas Kebangkrutan. Probabilitas kebangkrutan adalah peluang dengan nilai total aset perusahaan kurang dari nilai utang (face value) $K$ pada saat jatuh tempo. Hal itu menunjukkan bahwa perusahaan tidak mampu membayar utangnya dan perusahaan diambil alih atau mengalami kebangkrutan. Probabilitas kebangkrutan berdasarkan GBM Jump pada waktu jatuh tempo dengan satu kali periode pembayan kupon dirumuskan dengan [16]:

$$
\begin{aligned}
P_{D} & =\sum_{i=0}^{\infty} P\left(Q_{t}=i\right) P\left(\ln V_{T}<\ln K_{1}\right) \\
& =\sum_{i=0}^{\infty} P\left(Q_{t}=i\right) P\left[\ln V_{t}+\left(r-\frac{\sigma^{2}}{2}-\lambda k\right) \tau+\sigma W_{t}+\ln N_{i}<\ln K_{1}\right] \\
& =\sum_{i=0}^{\infty} \frac{e^{-\bar{\lambda} \tau}(\bar{\lambda} \tau)^{i}}{i !} P\left[\varepsilon<\frac{\ln K_{1}-\ln V_{t}-\left(r-\frac{\sigma^{2}}{2}-\lambda k\right) \tau-i k}{\sqrt{\tau \sigma^{2}+i \delta^{2}}}\right]
\end{aligned}
$$

$\varepsilon \sim N(0,1)$ sehingga probabilitas kebangkrutan pada saat jatuh tempo adalah 


$$
P_{D}=\sum_{i=0}^{\infty} \frac{e^{-\bar{\lambda} \tau}(\bar{\lambda} \tau)^{i}}{i !} N\left[\frac{\ln K_{1}-\ln V_{t}+\left(r-\frac{\sigma^{2}}{2}-\lambda k\right) \tau-i k}{\sqrt{\tau \sigma^{2}+i \delta^{2}}}\right]
$$

\section{Hasil dan Pembahasan}

Data in sample aset perusahaan yang digunakan untuk pemodelan diperoleh dari laporan keuangan PT Bank CIMB Niaga Tbk periode Januari 2012 - Desember 2016 dan data out sample yang digunakan untuk melihat ketepatan model merupakan data aset PT Bank CIMB Niaga Tbk periode Januari 2017 - Desember 2018. Data tersebut dapat diakses pada situs www.ojk.go.id. Sedangkan data yang digunakan untuk valuasi obligasi adalah data obligasi berkelanjutan II Bank CIMB Niaga Tahap III tahun 2017 seri B yang diperoleh dari website www.ibpa.co.id. Data aset yang tersedia selanjutnya dihitung nilai return berdasarkan compounding return asset sebagai dasar pemodelan GBM dan GBM Jump $[17,18]$.

Tabel 2. Data Obligasi PT Bank CIMB Niaga Tbk.

\begin{tabular}{ll}
\hline Data & Nilai \\
\hline Nama Obligasi & Obligasi Berkelanjutan II Bank CIMB \\
& Niaga Tahap III tahun 2017 Seri B \\
Penerbit & PT Bank CIMB Niaga Tbk. \\
Face Value (K) & Rp. 657.000.000.000,00 \\
Tanggal Penerbitan & 02 November 2017 \\
Tanggal Jatuh Tempo & 02 November 2020 \\
Jangka Waktu Obligasi & 3 Tahun \\
Rating & AAA \\
Kupon & $7,5 \%$ p.a \\
\hline
\end{tabular}

Data obligasi yang digunakan merupakan data sekunder yang diperoleh dari Lembaga Penilaian Harga Efek di Indonesia yaitu Indonesian Bond Pricing Agency (IBPA) yang diakses melalui website www.ibpa.co.id. Obligasi yang dipilih pada penelitian ini adalah obligasi berkelanjutan II Bank CIMB Niaga tahap III tahun 2017 seri B yang ringkasan data obligasinya disajikan pada Tabel 2.

Penghitungan statistik deskriptif bertujuan untuk memperoleh nilai kurtosis dan skewness. Nilai kurtosis dianggap sebagai indikator awal yang dapat menunjukkan 
keberadaan jump. Apabila nilai kurtosis berada di atas 3 maka data tersebut dianggap mengandung jump atau nilai ekstrem. Nilai statistik deskriptif disajikan pada Tabel 3.

Tabel 3. Statistik Deskriptif Data Ln Return Aset

\begin{tabular}{lc}
\hline \multicolumn{1}{c}{ Parameter } & \multicolumn{1}{c}{ Nilai } \\
\hline Rata-rata & 0,005814 \\
Varian & 0,000372 \\
Nilai terendah & $-0,068316$ \\
Nilai tertinggi & 0,055377 \\
Skewness & $-0,610279$ \\
Kurtosis & 5,797338 \\
\hline
\end{tabular}

Nilai volatilitas merupakan estimasi dari standar deviasi dari ln return bulanan aset PT Bank CIMB Niaga Tbk yang digunakan dari bulan Januari 2012 sampai dengan Desember 2016. Diperoleh nilai varian sebesar 0,000372 dengan banyaknya periode dalam satu tahun $(m)$ adalah 12 , maka nilai estimasi standar deviasi atau volatilitas dapat diperoleh:

$$
\sqrt{m \times s^{2}}=\sqrt{12 \times 0,000372}=0,066839
$$

Tabel 4. Nilai Kuantil Ambang Batas Atas dan Bawah

\begin{tabular}{lc}
\hline \multicolumn{1}{c}{ Kuantil } & Nilai \\
\hline Kuantil ambang batas bawah & $-0,013880$ \\
Kuantil ambang batas atas & 0,025864 \\
\hline
\end{tabular}

Karena data ln return bank CIMB terindikasi adanya jump, maka dilakukan perhitungan jumlah worse case data dengan extreme value menggunakan metode peak over treshold. Digunakan $\alpha=10 \%$ untuk menentukan nilai ambang batas bawah dan nilai ambang batas atas. Sebelum menentukan nilai kuantil ambang batas atas dan bawah data In return terlebih dahulu diurutkan dari yang terkecil hingga terbesar, sehingga diperoleh nilai kuantil ambang batas atas dan bawah yang dapat dilihat pada Tabel 4.

Ambang batas bawah memiliki nilai -0,013880. Artinya nilai return yang lebih rendah dari -0,013880 merupakan jump yang terjadi pada data ln return aset. Sebanyak 6 data bernilai negatif merupakan jump. Kuantil ambang batas atas merupakan batas atas 
nilai data ekstrem atau jump yang ditentukan dari nilai ln return aset. Ambang batas memiliki nilai 0,025864 . Artinya nilai ln return aset yang lebih tinggi dari 0,025864 merupakan jump yang terjadi pada data $\ln$ return aset. Sebanyak 6 data bernilai positif merupakan jump. Sehingga dari data dilakukan pemotongan 6 data terendah dan 6 data tertinggi.

Parameter dalam model GBM Jump meliputi rata-rata ln return $(\mu)$, volatilitas $\ln$ return $(\sigma)$, intensitas jump $(\lambda)$, rata-rata jump $(k)$, dan standar deviasi jump $(\delta)$. Diperoleh hasil seperti pada Tabel 5 .

Tabel 5. Estimasi Nilai Parameter Model GBM Jump

\begin{tabular}{lc}
\hline \multicolumn{1}{c}{ Parameter } & Nilai \\
\hline Rata-rata $\ln$ return $(\mu)$ & 0,005814 \\
Volatilitas $\ln$ return $(\sigma)$ & 0,066839 \\
Intensitas jump $(\lambda)$ & 0,004698 \\
Rata-rata jump $(k)$ & 0,011245 \\
Standar deviasi jump $(\delta)$ & 0,014007 \\
\hline
\end{tabular}

Nilai estimasi intensitas jump $(\lambda)$ merupakan rata-rata dari data jump yaitu sebesar 0,004698 , nilai estimasi rata-rata jump $(k)$ merupakan nilai rata-rata dari selisih data jump yaitu sebesar 0,011245 , dan nilai estimasi standar deviasi jump $(\delta)$ adalah nilai standar deviasi dari selisih data jump sebesar 0,014007. Nilai estimasi parameter yang diperoleh kemudian digunakan untuk memodelkan data ke dalam model GBM Jump berdasarkan persamaan (4) sebagai berikut

$$
\begin{gathered}
\widehat{V}_{t_{i}}=\widehat{V}_{t_{i-1}} \exp ( \\
\left.+\left(0,005814-\frac{(0,066839)^{2}}{2}-0,004698\right)\left(t_{i}-t_{i-1}\right)\right) \\
\left.+\left(0,066839 Z_{i-1} \sqrt{\left(t_{i}-t_{i-1}\right)}\right)+N_{i}\right)
\end{gathered}
$$

dengan

$\widehat{V}\left(t_{i}\right) \quad$ : nilai estimasi total aset pada waktu ke- $t_{i}$

$\widehat{V}\left(t_{i-1}\right)$ : nilai estimasi total aset pada waktu ke- $t_{i-1}$

$Z_{i-1} \quad$ : data bangkitan berdistribusi normal baku ke- $i-1$ 
$N_{i} \quad$ : data bangkitan berdistribusi normal dengan rata-rata $=0,011245$ dan variansi $=0,014007$.

Nilai prediksi total aset dan nilai aktual aset PT Bank CIMB Niaga disajikan pada Tabel 6. Nilai aktual dan hasil prediksi total aset PT Bank CIMB Niaga Tbk ini selanjutnya akan digunakan untuk menghitung nilai kesalahan prediksi, yang dapat menunjukkan apakah model GBM Jump memberikan hasil yang baik jika digunakan untuk memprediksi total aset pada kasus ini.

Perhitungan kesalahan prediksi total aset dilakukan menggunakan nilai MAPE dibandingkan dengan nilai aktual. Nilai MAPE diperoleh sebesar 3,870466 \% untuk data out sample yaitu untuk prediksi total aset bulan Januari 2017 hingga Desember 2018. Nilai MAPE yang sebesar 3,870466 \% tersebut menunjukkan bahwa model GBM Jump yang dihasilkan memberikan akurasi peramalan yang sangat baik. Sehingga model GBM Jump dapat digunakan untuk valuasi obligasi.

Tabel 6. Nilai Aktual dan Prediksi Total Aset PT Bank CIMB Niaga Tbk.

\begin{tabular}{lclllc}
\hline \multicolumn{1}{c}{ Periode } & Aktual & Prediksi & \multicolumn{1}{c}{ Periode } & Aktual & Prediksi \\
\hline Januari 2017 & 234612254 & 226129508 & Februari 2018 & 261251824 & 273487409 \\
Februari 2017 & 235566662 & 238904710 & Maret 2018 & 255689959 & 261190936 \\
Maret 2017 & 232771169 & 264281161 & April 2018 & 255577476 & 255145944 \\
April 2017 & 229501752 & 249137507 & Mei 2018 & 256276450 & 259106213 \\
Mei 2017 & 234043439 & 273695112 & Juni 2018 & 258203024 & 248355867 \\
Juni 2017 & 238302102 & 233763466 & Juli 2018 & 257464637 & 263591892 \\
Juli 2017 & 235351357 & 236106302 & Agustus 2018 & 256504818 & 257335876 \\
September 2017 & 249300982 & 258995633 & September 2018 & 259070857 & 247195834 \\
Oktober 2017 & 247724194 & 259345971 & Oktober 2018 & 260299892 & 239292014 \\
November 2017 & 247227333 & 243883710 & November 2018 & 256211135 & 257305086 \\
Desember 2017 & 264160781 & 267752590 & Desember 2018 & 265063937265629066 \\
\hline
\end{tabular}

Perbandingan berdasarkan prediksi data aset pada periode yang sama dengan pemodelan GBM berdasarkan persamaan (1) menunjukkan nilai MAPE yang lebih besar, yaitu $6,111993 \%$, sehingga Jump lebih tepat digunakan sebagai dasar valuasi obligasi yang diterbitkan Bank CIMB Niaga. Hal ini sesuai dengan kesimpulan yang diperoleh pada penelitian sebelumnya $[7,8]$. 
Untuk mengetahui nilai aset pada saat jatuh tempo tersebut, dilakukan prediksi menggunakan model GBM Jump yang telah terbentuk dengan $\widehat{V}_{t_{i}}$ total aset perusahaan pada saat obligasi jatuh tempo yaitu pada bulan November 2020. $\widehat{V}_{t_{i-1}}$ merupakan total aset perusahaan pada saat obligasi diterbitkan yaitu pada bulan November 2017 sebesar Rp 247.227.333.000.000,00. Jangka waktu hingga obligasi jatuh tempo yaitu 3 tahun adalah $t_{i}-t_{i-1}$. Estimasi nilai aset pada saat jatuh tempo pada tanggal 2 November 2020 berdasarkan persamaan (5) diperoleh sebesar Rp 250.739.325.000.000,00.

Penentuan ekuitas perusahaan digunakan nilai suku bunga bebas risiko yang diambil dari rata-rata suku bunga dari November 2017 hingga Desember 2018 yaitu sebesar $4,95 \%$. Sedangkan untuk nilai c dan $K_{1}$ diperoleh dari

$$
c=7,5 \% \times K=7,5 \% \times 657.000 .000 .000,00=49.275 .000 .000,00
$$

Karena nilai kupon obligasi 7,5\% diberikan per tahun dengan waktu jatuh tempo 3 tahun maka nilai $c$ dikalikan 3, sehingga didapatkan $K_{1}=K+3 c=804.825 .000 .000,00$

Oleh karena itu, nilai ekspektasi ekuitas berdasarkan persamaan (6) sebesar

$$
\begin{aligned}
= & \sum_{i=0}^{11}\left[\frac{e^{-0,004750 \tau}(0,004750 \tau)^{i}}{i !}\right] 247227333000000 N\left(\frac{\ln \left(\frac{247227333}{804825}\right)+\left(r_{i}+\frac{\sigma_{i}^{2}}{2}\right) \tau}{\sigma_{i} \sqrt{\tau}}\right) \\
& -804825000000 e^{-r_{i} \tau} N\left(\frac{\ln \left(\frac{247227333}{804825}\right)+\left(r_{i}-\frac{\sigma_{i}^{2}}{2}\right) \tau}{\sigma_{i} \sqrt{\tau}}\right) \\
= & 246.533 .573 .844 .229,00
\end{aligned}
$$

Liabilitas merupakan hutang atau kewajiban yang harus dibayarkan. Nilai liabilitas berkaitan dengan nilai total aset dan nilai ekuitas. Berdasarkan persamaan (6) diperoleh nilai liabilitas sebesar

$$
F\left(V_{T}, \tau\right)=250.739 .325 .000 .000,00-246.533 .573 .844 .229,00
$$




$$
=4.205 .751 .155 .771,00
$$

Nilai probabilitas kebangkrutan berdasarkan persamaan (7) dengan $k$ adalah ratarata ln return jump, $\delta^{2}$ merupakan variansi dari jump, maka diperoleh nilai probabilitas kebangkrutan sebesar $1,065812 \times 10^{-8}$. Hasil tersebut menunjukkan bahwa kemungkinan PT Bank CIMB Niaga Tbk mengalami kebangkrutan sangat kecil. Berdasarkan hasil tersebut dapat dikatakan bahwa PT Bank CIMB Niaga memiliki performa yang baik untuk dapat membayar hutang obligasi pada saat jatuh tempo.

Ukuran peluang kebangkrutan ini bisa dikatakan akurat dan valid dengan dasar bahwa underlying assets dimodelkan dengan metode yang sesuai dengan karakteristik data. Hasil yang sama juga ditunjukkan pada penelitian sebelumnya pada valuasi obligasi Zero Coupon Bond [19]. GBM mempunyai prediksi yang baik dilihat dari ukuran MAPE yang kecil, akan tetapi keberadaan data ekstrem tidak terakomodasi pada model tersebut. Pemodelan GBM Jump menghasilkan akurasi yang lebih baik, dan berdasarkan pola data yang diuji di awal menunjukkan keberadaan data-data ekstrem. Valuasi yang diperoleh berdasarkan GBM Jump dapat digunakan sebagai bahan pertimbangan investor maupun Bank CIMB Niaga dalam mengelola perusahaan karena diukur berdasarkan karakteristik data aset Bank CIMB Niaga.

\section{Kesimpulan}

Berdasarkan hasil analisis yang dihasilkan untuk kasus PT Bank CIMB Niaga Tbk tersebut, diperoleh kesimpulan bahwa model Geometric Brownian Motion dengan Jump Diffusion yang terbentuk adalah sebagai berikut

$$
\begin{gathered}
\widehat{V}_{t_{i}}=\widehat{V}_{t_{i-1}} \exp \left(\left(\left(0,005814-\frac{(0,066839)^{2}}{2}-0,004698\right)\left(t_{i}-t_{i-1}\right)\right)\right. \\
\left.+\left(0,066839 Z_{i-1} \sqrt{\left(t_{i}-t_{i-1}\right)}\right)+N_{i}\right)
\end{gathered}
$$

Hasil valuasi terhadap obligasi berkelanjutan II Bank CIMB Niaga tahap III tahun 2017 seri B diperoleh ekspektasi ekuitas pada saat obligasi jatuh tempo pada tanggal 2 November 2020 yaitu sebesar Rp 246.533.573.844.229,00. Sedangkan untuk ekspektasi utangnya atau liabilitas pada saat jatuh tempo adalah sebesar $\mathrm{Rp}$ 4.205.751.155.771,00. Serta diperoleh nilai probabilitas kebangkrutan yang sangat kecil 
yaitu sebesar $1,065812 \times 10^{-8}$, yang berarti bahwa kemungkinan PT Bank CIMB Niaga

Tbk tidak mampu membayar utangnya sangat kecil. Berdasarkan hal tersebut dapat disimpulkan bahwa PT Bank CIMB Niaga Tbk memiliki performa yang cukup baik dalam melunasi utangnya.

Model ini cukup akurat dipandang dari hasil perbandingan dengan menggunakan GBM, akan tetapi dengan karakteristik data yang lebih kompleks, memungkinkan untuk dapat dikembangkan dengan kasus volatility clustering pada data, sifat asimetris data, dan sebagainya.

\section{Ucapan Terima Kasih}

Artikel ini didanai oleh Kementerian Pendidikan dan Kebudayaan, Direktorat Riset dan Pengabdian Kepada Masyarakat melalui Penelitian Terapan Unggulan Perguruan Tinggi, dengan nomor kontrak 101-112/UN7.6.1/PP/2020.

\section{Daftar Pustaka}

[1] Maruddani, D.A.I., Rosadi, D., Gunardi, dan Abdurakhman. Valuation of One Period Coupon Bond Based on Default Time and Empirical Study in Indonesian Bond Data. Far East Journal of Mathematical Sciences, Vol. 98 (1), 57-73. 2015.

[2] Landschoot, A.V. Determinants of Euro Term Structure of Credit Spreads, Working Paper Series No.397, European Central Bank. 2004.

[3] Abidin, S.N.Z. dan Jaffar, M.M. Forecasting Share Prices of Small Size Companies in Bursa Malaysia Using Geometric Brownian Motion. Applied Mathematics \& Information Sciences. Vol. 8 (1), 107-112. 2014.

[4] Trimono, Maruddani, D.A.I., dan Ispriyanti, D. Pemodelan Harga Saham Dengan Geometric Brownian Motion dan Value At Risk PT Ciputra Development Tbk. Gaussian, Vol. 6 (2), 261 - 270. 2017.

[5] Rosso, G. Extreme Value Theory for Time Series using Peak-Over-Threshold Method. Working Paper. 2015.

[6] Trimono dan Maruddani, D.A.I. Valuasi Harga Saham PT Aneka Tambang Tbk sebagai Peraih IDX Best Blue 2016. Statistika, Vol 17(1), 33 - 43. 2017.

[7] Maruddani, D.A.I. dan Trimono. Prediksi Harga Saham PT. Astra Agro Lestari Tbk. dengan Jump Diffusion Model. Jurnal Riset Akuntansi Mercu Buana, Vol. 3(1), $57-67.2017$.

[8] Abdurakhman dan Maruddani, D.A.I. Pengaruh Skewness dan Kurtosis dalam Model Valuasi Obligasi. Media Statistika, Vol. 11(1), hal 39-51. 2018.

[9] Abdurakhman dan Maruddani, D.A.I. Comparing Merton model and GramCharlier model to Capture Skewness and Kurtosis on Bond Performance. Journal of Physics Conference Series, Vol. 1217. 2019.

[10] Maruddani, D.A.I. Pengaruh Data Ekstrim Aset Perusahaan Pada Valuasi Obligasi. Prosiding Seminar Nasional Variansi 2018, hal 221-233. 2018. 
[11] Brigo, D., Dalessandro, A., Neugebauer, M., dan Triki, FA Stochastic Processes Toolkit for Risk Management. Journal of Risk Management in Financial Institutions. Vol. 1 (4), 5-13. 2008.

[12] Matsuda, K. Introduction to Merton Jump Diffusion Model. Working Paper The City University of New York. 2004.

[13] Merton, R.C. On the Pricing of Corporate Debt: The Risk Structure of Interest Rate. Journal of Finance, Vol 29, 449-470. 1974.

[14] Cont, R. dan Tankov, P. Financial Modeling with Jump Processes. Chapman \& Hall / CRC Financial Mathematics Series. 2004.

[15] Storeng, H.B. Jump-Diffusion Models for Option Pricing Versus the Black Scholes Model. Norwegian School of Economic, 1-77. 2014.

[16] Zhou, C. A Jump-Diffusion Approach to Modeling Credit Risk and Valuing Defaultable Securities. Federal Reserve Boards Working Paper. 1997.

[17] Maruddani, D.A.I. Value at Risk untuk Pengukuran Risiko Investasi Saham: Aplikasi dengan Program R. Wade Group, Ponorogo. 2019.

[18] Maruddani, D.A.I. dan Trimono. Microsoft Excel untuk Pengukuran Value at Risk: Aplikasi pada Risiko Investasi Saham. Undip Press. Semarang. 2020.

[19] Maruddani, D.A.I., Abdurakhman, Safitri, D. The Effect of Extreme Asset Prices to The Valuation of Zero Coupon Bond with Jump Diffusion Processes. Journal of Physics Conference Series, Vol. 1217. 2019b. 